\title{
THE ROLE OF SALPINGOSCOPY IN TUBAL FACTOR OF INFERTILITY
}

\author{
El-Gharib MN; Anamouri $M$ and *Sabri, $M Y$ \\ From Departments of Obstetrics \& Gynaecology, Faculty of Medicine, Tanta University, \\ and *El-Mataria Teaching Hospital
}

\section{ABSTRACT}

Objective : To evaluate the role of the salpingoscope in the prediction of reproductive outcome in eases of female infertility and to correlate these findings with salpingographic and laparoscopic findings.

Design: Prospective study.

Setting : Tanta University Hospitals and El-Mataria Teaching Hospital.

Patients : The study was carried out on 30 women during the reproductive age; 17 were primary infertile amd 13 were secondary infertile.

Intervention: All the patients were subjected to history taking, physical examination, HSG, laparoscopy and salpingoscopy under general anesthesia.

Outcome measures: Pregnancy occurred in $56.7 \%$ of cases reported as salpingoscopically normal and in $33.3 \%$ of cases found to be abnormal salpingoscopically and treated.

Results: There was a discrepancy between findings detected by HSG and those found by laparoscopy. Laparoscopy examinatien revealed that pelvic and peritubal abnormalities were also found in $13.56 \%$ of cases diagnosed normal by HSG. We also found a discrepancy between salpingoscopic and salpingographic findings. Fifty live Fallopian tubes were considered normal by HSG; 11 of these tubes (18.6\%) were proved by salpingoscopy to have intratubal pathology. This study demonstrated that there is also discrepancy between findings at laparoscopy and those of salpingoseopy when both were done at the same setting as $71.2 \%$ of the studied tubes were considered laparoscopically free of tubal pathology, $20 \%$ of them were proved salpingoscopically to have intratubal pathology.

Conclusion: Both laparoscopy and salpingoscopy are complementary procedures and their combination should be a standard part of the investigations.

Key words: Salpingoscopy, tubal infertility, laparoscopy.

\section{INTRODUCTION}

Tubal factor in infertility accounts for approximately $30-50 \%$ of cases of female infertility ${ }^{(1)}$. The commonest causes of tubal factors in infertility include infectious and non-infectious causes. The infectious causes may not be originated in the female reproductive system or originated in the female reproductive system (as obstetrical). The non infectious causes include endometriosis, myomatosis and agenesis $^{(2)}$. There are 4 diagnostic techniques that are used to explore the tubal factor in the infertile patient. These techniques are: hysterosalpingography, sonohysterography, Laparoscopy and salpingoscopy ${ }^{(3)}$.
Intraluminal tubal endoscopy may be performed through the transvaginal route (falloposcopy) or by the transabdominal (salpingoscopy) approach ${ }^{(4,5)}$.

The aim of this work was to evaluate the role of the salpingoscope in the prediction of reproductive outcome in cases of female infertility and to correlate these findings with salpingographic and laparoscopic findings.

\section{MATERIALS \& METHODS}

This study was conducted upon patients attending the outpatient clinics of the Obstetrics and Gynecology Department, Tanta University Hospital, 
and El-Mataria Teaching Hospital complaining of infertility whether primary or secondary during the period from June 2002 until June 2005.

The study group consisted of 30 patients who were selected from 77 patients with history of primary infertility in 17 cases and secondary infertility in 13 cases. For each patient included in this study the following was carried out: history taking clinical examinations and routine blood examination. Investigations required for infertility work up, namely: semen analysis, pelvic U/S and HSG, and hormonal profile were done when required.

Patients with bilateral hysterosalpingographic abnormalities or abnormal semen analysis were excluded from this study.

All patients were subjected to laparoscopy and salpingoscopy under general anesthesia. Also, hysteroscopy was done in some patients when required.

All the procedures had been done during the proliferative phase of the menstrual cycle to exclude current pregnancy and to minimize bleeding at operative laparoscopy or salpingoscopy.

The observed salpingoscopic findings were tabulated according to Brosens classification of tubal mucosal lesions ${ }^{(6)}$.

\section{RESULTS}

The 30 patients in the study represent 59 Fallopian tubes for examination as one case had only one tube sicne the other one was removed after ectopic tubal pregnancy (tables I-V).

The age of the patients ranged from 20 and 38 years with a mena of $31.33 \pm 4.96$ years.

The mean duration of infertility was $4.83 \pm 2.21$ years with a range of 2-11 years.

Seventeen cases $(56.6 \%)$ were primary infertile while 13 cases $(43.3 \%)$ were secondary infertile.

All patients in the study were evaluated by HSG. Hysterosalpingographic evaluation of the Fallopian tubes revealed that 56 tubes $(94.92 \%)$ were patent.

\section{DISCUSSION}

The importance of tubal obstruction as a major cause of infertility was recognized by Burns ${ }^{(7)}$. Since that time a number of methods of demonstrating tubal patency have been described. These include transcervical insufflation with gas, injection of radio-opaque or echogenic contrast media and chromopertubation during laparoscopy. Patency may also be confirmed by cannulation which can be performed by tactile method or under hysteroscopic, ultrasonic or fluoroscopic guidance ${ }^{(8)}$.

There may be discrepancies between the findings at HSG, laparoscopy and intraluminal endoscopy in the presence of peritubal adhesions or endometriosis. It is well known that a HSG is not entirely reliable and has poor conceordnace with endoscopic findings (7). Patency of the distal tube does not necessarily equate with normality of the mucosa and pathological lesions may be missed if more accurate methods of tubal assessment were not employed.

Until recently there was no endoscopic technique available for examining the tubal mucosa and it had to be assumed that normal findings at HSG and laparoscopy equated with a normal tubal patency and anatomy. Close examination of the fimbrial mucosa at the time of tubal microsurgery had been introduced already using micro biopsies, the operating microscope or an endoscope ${ }^{(9)}$.

Evaluation of the pelvis in infertile women was classically performed first by HSG, completed by diagnostic laparoscopy in cases of abnormal HSG findings or when unexplained infertility is suspected, before referring the patient to in vitro fertilization (IVF). However, if investigation is limited to HSG and laparoscopy alone, accurate assessment of the Fallopian tube can not be overstated ${ }^{(10)}$.

Since the first report on the value of salpingoscopy at the time of tubal microsurgery, there had been an increasing interest in the salpingoscopic technique to detect intraluminal lesions which may be 
inversely correlated with pregnancy outcome $\mathrm{c}^{(4)}$.

Salpingoscopy is the logical extension of laparoscopic surgery for the evaluation of the endosalpinx as it provides direct visualization of the internal tubal anatomy (6).
The American Society of Reproductive Medicins recognized the importance of intraperalive salpingoscopy to visualize the entire length of the ampuliary mucosa and proved that it has an importimi prognostic value (7).

Table I: Laparoscopic findings.

\begin{tabular}{|l|c|c|}
\hline \multicolumn{1}{|c|}{ Laparoscopy finding } & No. of tubes & $\%$ \\
\hline Peritubal adhesions & 8 & 13.56 \\
\hline Pelvic endometriosis & 6 & 10.18 \\
\hline * Delayed spill of dye & 12 & 20.33 \\
\hline Others (PCO) & 9 & 15.25 \\
\hline Normal tubes & 24 & 40.68 \\
\hline
\end{tabular}

* N.B. Delayed spill of the dye means positive methylene blue test with patent tube but the spill of the dye was delayed. So, these tubes are considered normal as regards statistical analysis however, this laparoscopic finding could not be by - passed as it pertains good relation to fertility outcome.

Table II: Salpingoscopic findings.

\begin{tabular}{|l|c|c|}
\hline \multicolumn{1}{|c|}{ Laparoscopy finding } & No. of tubes & $\%$ \\
\hline Adhesions between major folds (Grade III lesion) & 6 & 10.2 \\
\hline Flattening and separation of folds (Grade II lesion) & 2 & 3.3 \\
\hline (Grade II and III lesions) & 3 & 5.1 \\
\hline Grades IV and V lesions & 00 & 00 \\
\hline Normal tube & 48 & 81.3 \\
\hline
\end{tabular}

Table III: Comparison between Hysterosalpingography and salpingoscopy.

\begin{tabular}{|c|c|c|c|}
\hline \multicolumn{2}{|c|}{ Normal tube by HSG } & \multicolumn{2}{c|}{ Normal tube by salpingoscopy } \\
\hline No. & $\%$ & No. & $\%$ \\
\hline 59 & $100 \%$ & 48 & $81.3 \%$ \\
\hline
\end{tabular}

Table IV: Comparison between laparoscopic and salpingoscopy findings.

\begin{tabular}{|c|c|l|l|}
\hline \multicolumn{3}{|c|}{$\begin{array}{c}\text { Tubal abnormalities detected by } \\
\text { laparoscopy }(\mathbf{n}=\mathbf{3 0})\end{array}$} & \multicolumn{1}{c|}{$\begin{array}{c}\text { Salpingoscopic evaluation } \\
(\mathbf{n}=\mathbf{3 0})\end{array}$} \\
\hline No & $\%$ & Laparoscopic findings & \\
\hline 4 & 13.3 & Pelvic adhesions & All tubal mucosa were free by salpingoscopy. \\
\hline 6 & 20 & Delayed spill of dye & Filmy adhesions or $\uparrow \uparrow$ mucous in the lumen. \\
\hline 3 & 10 & Pelvic endometriosis & all tubal mucosa were free by salpingoscopy. \\
\hline
\end{tabular}

From table (IV) it is evident that while laparoscopy was superior in detecting both pelvic and peritubal abnormailties, salpingoscopy was superior in detecting endotubal abnormalities. 
Table V: Shows operative findings \& management of all patients in the study.

\begin{tabular}{|c|c|c|c|c|}
\hline Pt. & Laparoscopic findings & Salpingoscopic findings & Management & Outcome \\
\hline 1 & $\begin{array}{l}\text { Bilateral delayed spill of } \\
\text { the dye with } \mathrm{PCO}\end{array}$ & $\begin{array}{l}\text { Grade III bilateral lesion } \\
\text { (Thin adhesions between } \\
\text { major folds) }\end{array}$ & $\begin{array}{l}\text { Intraluminal adhesiolysis } \\
\text { by the leading edge of the } \\
\text { salpingoscope }\end{array}$ & $\begin{array}{l}\text { Delivery of full term } \\
\text { living } 0^{\circ}\end{array}$ \\
\hline 4 & Minimal pelvic adhesions & NAD & Adhesialysis & Unknown \\
\hline 6 & $\begin{array}{l}\text { Pelvic adhesion } \\
\text { (Perforated appendix) }\end{array}$ & NAD & $\begin{array}{l}\text { Adhesiolysis with R!. } \\
\text { fimbriostomy }\end{array}$ & $\begin{array}{l}\text { Delivery of full term } \\
\text { living } 0\end{array}$ \\
\hline 8 & Endometriosis (stage II) & $\mathrm{NAD}$ & Adhesiolysis & Expectant follow up \\
\hline 9 & Bilateral PCO & $\uparrow \uparrow$ viscid mucous & Adhesiolysis & Expectant follow up \\
\hline 10 & $\begin{array}{l}\text { Patent both tubes; delayed } \\
\text { spill from fimbriac }\end{array}$ & $\begin{array}{l}\uparrow \uparrow \text { viscid mucous } \\
\text { secretion (inspissated) }\end{array}$ & $\begin{array}{l}\text { Hysteroscopic wash of the } \\
\text { mucous }\end{array}$ & $\begin{array}{l}\text { Delivery of full term } \\
\text { living o }\end{array}$ \\
\hline 11 & $\begin{array}{l}\text { Bilateral PCO + Normal } \\
\text { tubes }\end{array}$ & NAD & Nóthing & Expectant follow up \\
\hline 12 & NAD & $\begin{array}{l}\text { Grade III (Agglutination + } \\
\text { adhesion bet. RL, folds) }\end{array}$ & $\begin{array}{l}\text { R1. Iubal cannulation \& } \\
\text { selective chromotubation }\end{array}$ & $\begin{array}{l}\text { Delivery of full term } \\
\text { living } 9\end{array}$ \\
\hline 13 & $\begin{array}{l}\text { Rt. peritubal adhesion } \\
\text { (previous appendectomy) }\end{array}$ & NAD & Adhesiolysis & Unknown \\
\hline 15 & NAD & $\begin{array}{l}\uparrow \uparrow \text { inspissated mucous } \\
\text { inside both tubes }\end{array}$ & $\begin{array}{l}\text { Hysteroscopical wash of } \\
\text { the mucous }\end{array}$ & $\begin{array}{l}\text { Delivery of full term } \\
\text { living } 9\end{array}$ \\
\hline 16 & $\begin{array}{l}\text { Bilateral PCO + Normal } \\
\text { lubes }\end{array}$ & NAD & Nothing & Unknown \\
\hline 17 & $\begin{array}{l}\text { Bilateral peritubal } \\
\text { adhesion. (previous } \\
\text { appendectomy) }\end{array}$ & NAD & Adhesiolysis & $\left\{\begin{array}{l}\text { Pregnancy ended by } \\
\text { abortion at } 18 \text { weeks }\end{array}\right.$ \\
\hline 18 & Endometrios is (stage IlI) & NAD & Adhesiolysis & Unknown \\
\hline 19 & $\begin{array}{l}\text { Delayed spill of Rt. tube } \\
\text { (Lt. tube absent alter } \\
\text { ectopic tubal pregnancy) }\end{array}$ & $\begin{array}{l}\text { Grade II \& III lesions } \\
\text { (adhesions on major folds } \\
\text { of Rt, tube) }\end{array}$ & $\begin{array}{l}\text { Intraluminal adhesiolysis } \\
\text { by the leading edge of the } \\
\text { salpingoscope }\end{array}$ & $\begin{array}{l}\text { Pregnancy ended by } \\
\text { abortion at } 12 \text { weeks }\end{array}$ \\
\hline 20 & $\begin{array}{l}\text { Delayed spill of dye from } \\
\text { both fimbriae }\end{array}$ & $\begin{array}{l}\text { Grade III (Bilateral fine } \\
\text { filmy focal adhesions) }\end{array}$ & $\begin{array}{l}\text { Fine dissection of } \\
\text { intraluminal adhesions }\end{array}$ & $\begin{array}{l}\text { Delivery of full term } \\
\text { living } 0\end{array}$ \\
\hline 21 & NAD & $\begin{array}{l}\text { Grade II \& ILI lesions + } \\
\text { thin adhesion (Bilateral) }\end{array}$ & $\begin{array}{l}\text { Fine dissection of } \\
\text { incraluminal adhesions }\end{array}$ & $\begin{array}{l}\text { Delivery of full term } \\
\text { living } 0^{7}\end{array}$ \\
\hline 22 & Endometrosis (stage II) & NAD & $\begin{array}{l}\text { Cauterzation of the } \\
\text { endometriotic spots }\end{array}$ & $\begin{array}{l}\text { Delivery of full lerm } \\
\text { living } 9\end{array}$ \\
\hline 24 & $\begin{array}{l}\text { Bilateral PCO } \\
\text { Normal tubes }\end{array}$ & NAD & Nothing & $\begin{array}{l}\text { Delivery of full term } \\
\text { living } 9\end{array}$ \\
\hline 26 & $\begin{array}{l}\text { Delayed spill of dye from } \\
\text { both tubal fimbriae }\end{array}$ & $\begin{array}{l}\uparrow \uparrow \text { viscid mucous } \\
\text { (inspissated) }\end{array}$ & $\begin{array}{l}\text { Dilatation of both tubal } \\
\text { fimbriae }\end{array}$ & Expectant follow up \\
\hline 27 & $\begin{array}{l}\text { No Abnormal Data } \\
\text { (NAD) }\end{array}$ & $\begin{array}{l}\text { Bilateral Grade II } \\
\text { (Gattening \& separation of } \\
\text { folds) }\end{array}$ & $\begin{array}{l}\text { Dilatation of the tubal } \\
\text { fimbriae }\end{array}$ & $\begin{array}{l}\text { Delivery of full term } \\
\text { living } o^{\prime}\end{array}$ \\
\hline 30 & $\begin{array}{l}\text { Delayed spil of dye from } \\
\text { the tubes }\end{array}$ & $\begin{array}{l}T \uparrow \text { mucous \& debris } \\
\text { inside the } L t \text {. tube }\end{array}$ & $\begin{array}{l}\text { Lavage of the intraluminal } \\
\text { mucous }\end{array}$ & $\begin{array}{l}\text { Delivery of full term } \\
\text { living of }\end{array}$ \\
\hline
\end{tabular}

Cases No.2,3,5,7,14,23,26,28 and 29 had normal bolh laparoscopic and salpingoscopic findings. Among them 4 cases got pregnant one of them ended by abortion at 14 weeks and the other 3 ended by vaginal delivery of full term living babies. No complications were recorded whether intra or post operatively in all cases. NAD = No Abnormalities Detected. 


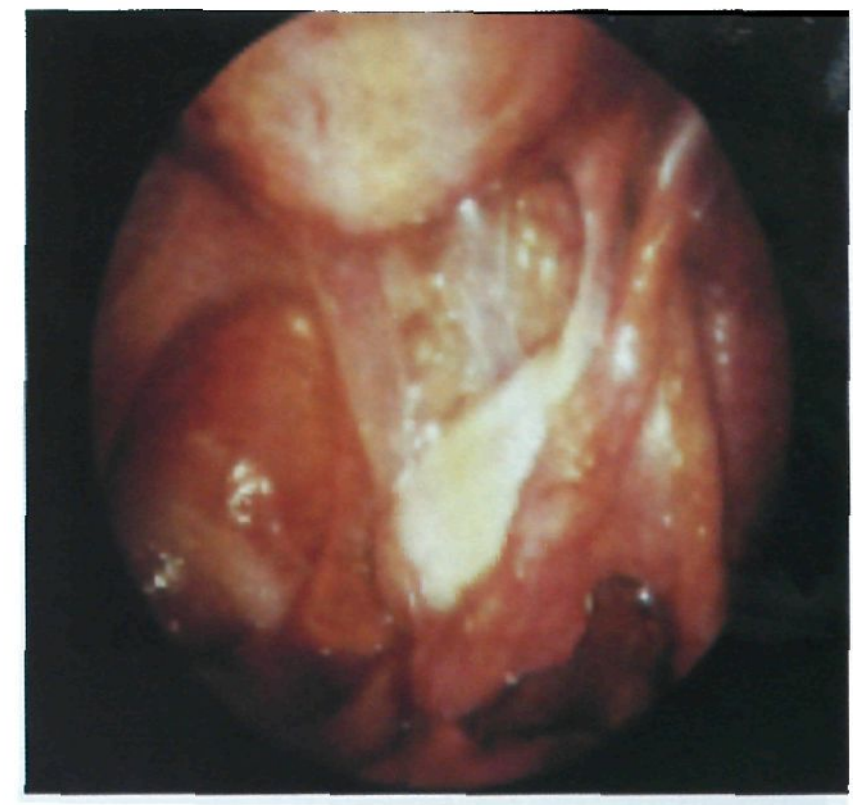

Fig. I. Perovarian \& tubal adhesions

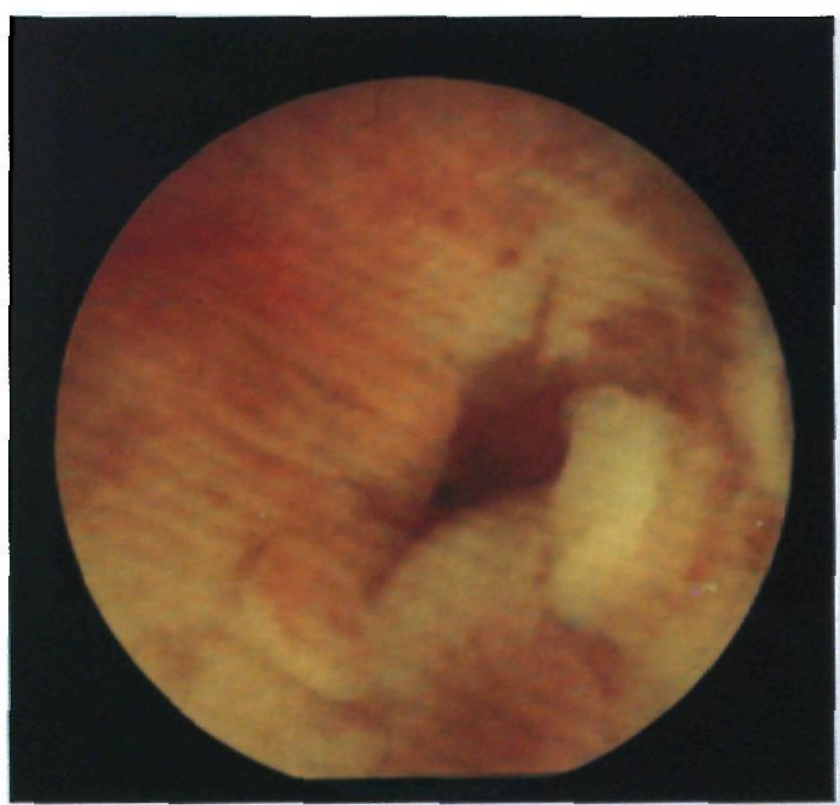

Fig. 3. Grade III Lesions with extensive adhesions

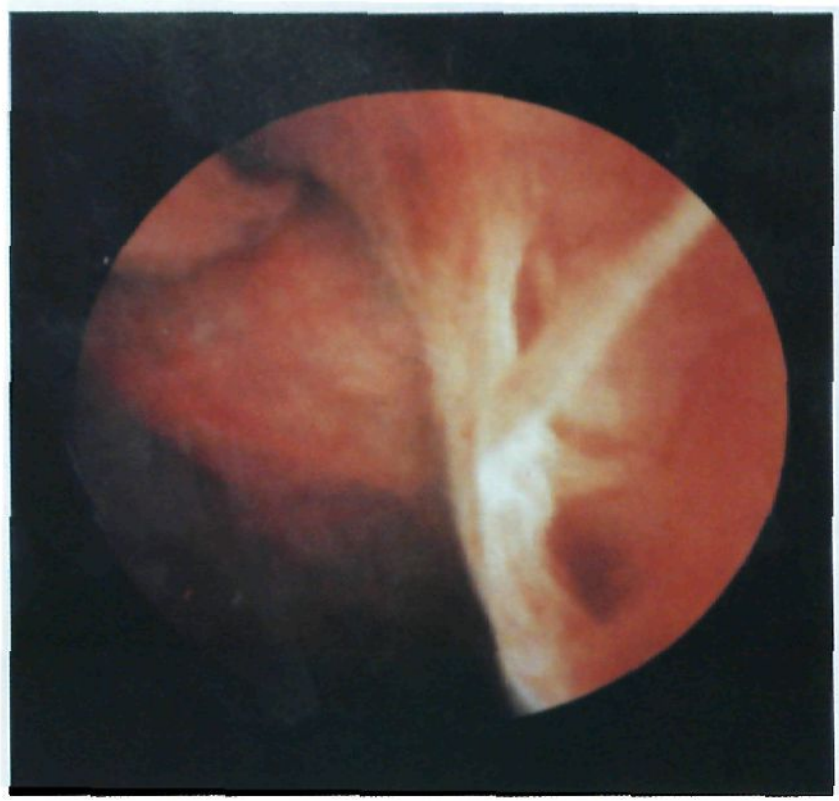

Fig. 2. Grade II Focal adhesions

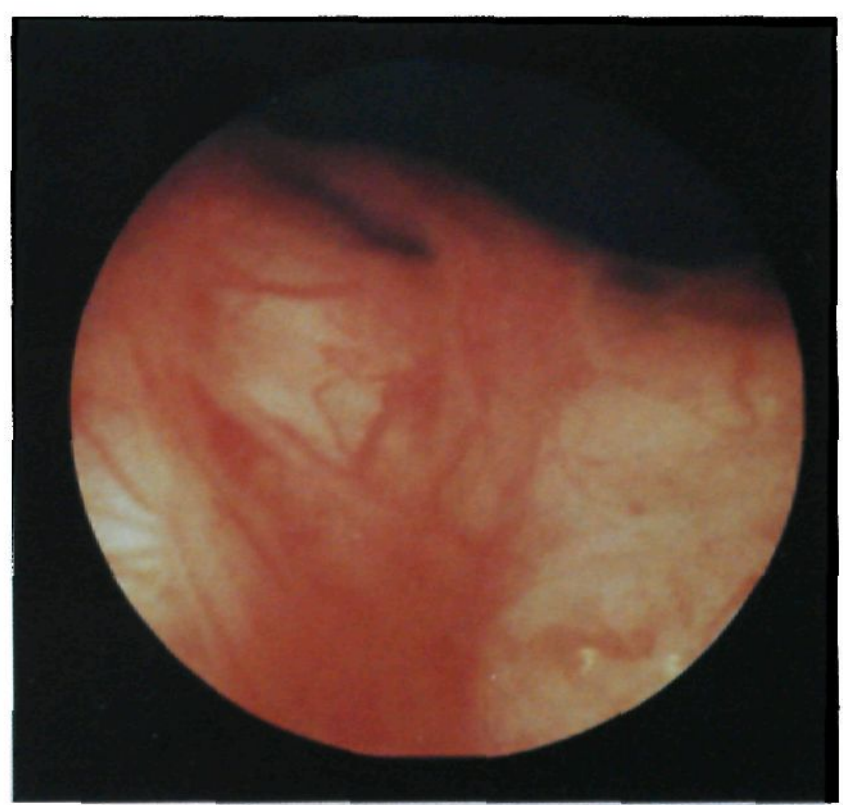

Fig. 4. Grade III Lesions with focal agglutination of mucosal folds 


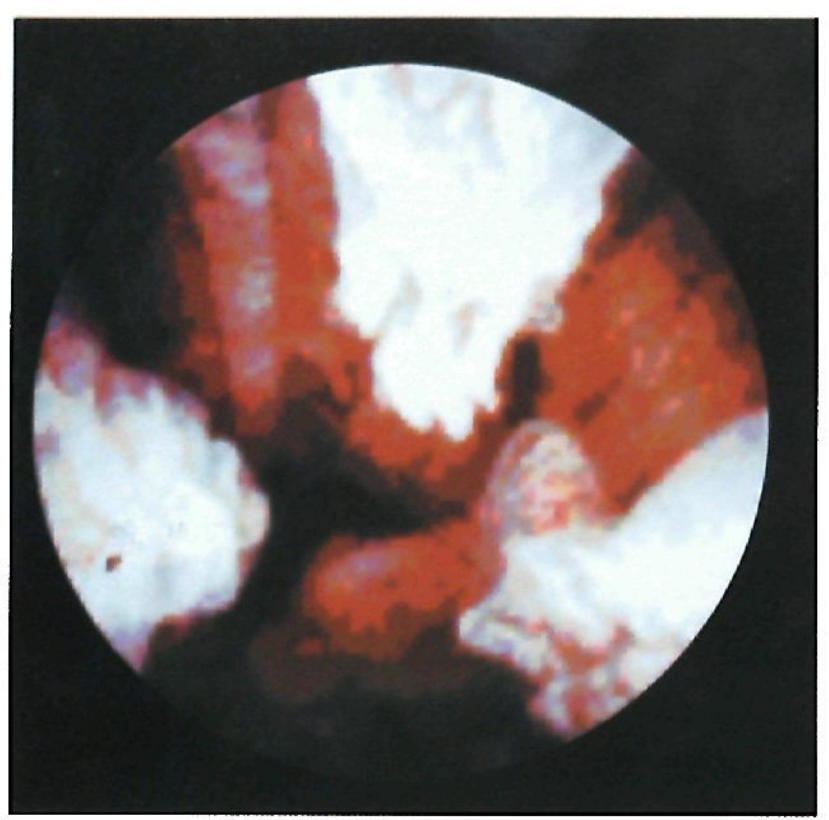

Ï̈g. 5. Tubal annpullat

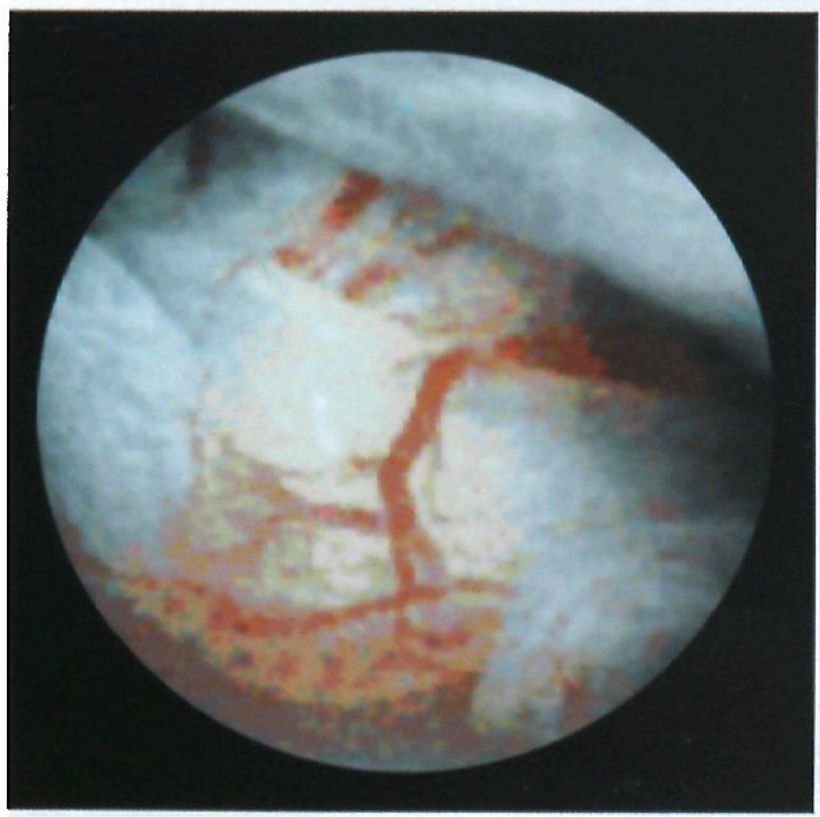

Fig. 7. Vascular pattern of major fold

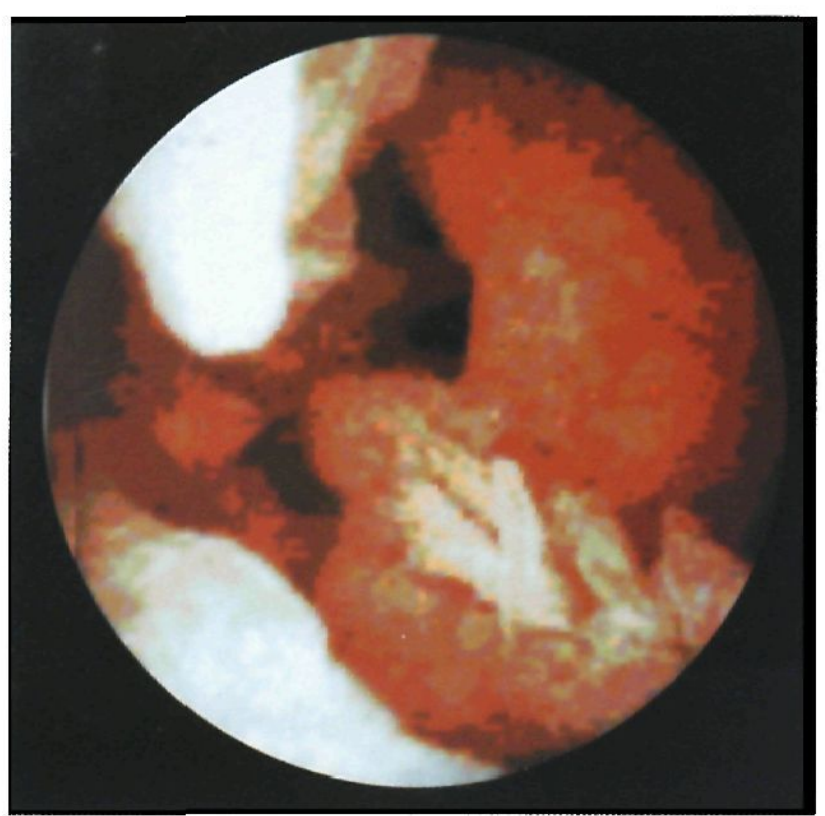

Fig. 6. Isthmico-ampullary junction

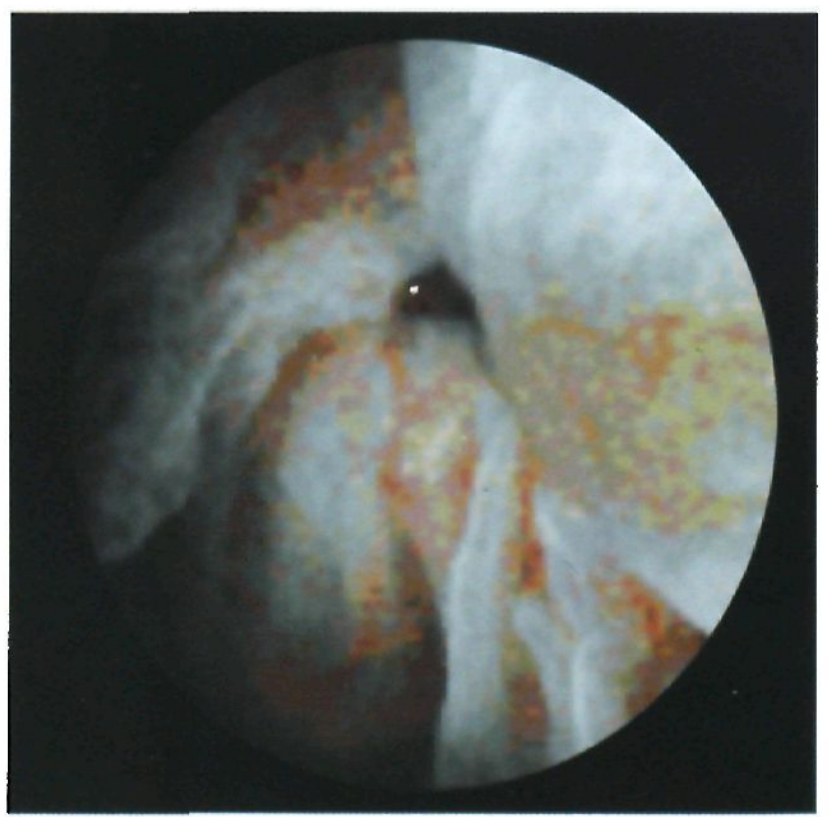

Fig. 8. Normal tubal mucotsa 
Detajled examination of the mucosa of the distal segment of the fallopian tube has an important role in the investigation of infertility work up. The intact fold structure of the mucosa with its secretory and ciliated cells is essential for normal gamete-transport and fertilization ${ }^{(6)}$.

With salpingoscopy, using a simple classificacion system, a trained endoscopist can evaluate the sequelae of tubal inflammatory disease and their impact on fertility outcome nearly as efficiently as with mucosal microbiopsies and they can direct their patients accordingly either towards reconstructive (micro) surgery or towards medically assisted reproduction, one of the most difficult decisions in reproductive surgery today $(11)$.

The present study showed that there is discrepancy between findings detected by HSG and those found by laparoscopy. Laparoscopy examination revealed that pelvic and peritubal abnormalities were also found in $13.56 \%$ of cases diagnosed normal by HSG. These findings are similar to those previously reported by many authors $(13,9$ and 14$)$. These studies reported that HSG is not a very accurate method to investigate tubal disease compared with the results obtained by laparoscopy which revealed abnormalities not detected by HSG as regards patency, peritubal and pelvic adhesions.

The present study showd that there is also discrepancy between salpingoscopic and salpingographic findings. Fifty five Fallopian tubes were considered to be normal by HSG; 11 of these tubes $(18.6 \%$ ) proved by salpingoscopy to have intratubal pathology.

These findings are in agreement with those reported by many other authors who reported the superiority of salpingoscopy over HSG in the assessment of tubal mucosa and stated that "HSG is not entirely reliable and has poor concordance with salpingoscopic findings since the latter is a direct visualization of the interior of the tube" $(4,14,6,16$ and 17).

The result of the current investigation demonstrated that there is also discrepancy between findings at laparoscopy and those of salpingoscopy when both were done at the same setting. Tubal morphology at laparoscopy was defined as regular (normal morphology), convoluted (any kind of distortion or adhesions), or hydrosalpinx. Laparoscopic and salpingoscopic finclings did not corrclate. We found that 42 lubes $(71.2 \%)$ were considered laparoscopically to be iree of tubal pathology (methylene blue test positive on one or both sides). However, 6 of them $(20 \%)$ proved salpingoscopically to have intratubal pathology.

Our previous findings are similar to those previously reported by several authors who found marked mucosal damage at salpingoscopy in $(18.7 \%),(21.2 \%)$ and $(22 \%)$ of cases respectively which were considered laparoscopically to be free or had minimal pelvic adhesions $(4,18$ and 19$)$.

On the contrary, Boweman and associales reported good correlation between intraluminal adhesions at salpingoscopy and pelvic adhesions found by laparoscopic examination in $66.6 \%$ of cases ${ }^{(20)}$.

This discrepancy may be explained by the ract that most cases included in their studies had extensive pelvic adhesions which may be a result of severe pelvic inflammatory discase causing extensive peritubal and endotubal adhesions. This can be also explained by the modification of salpingoscopy (which had been done since 1989) from a flexible fiberscope (used in their study) which does not allow direct visualization of the endosalpinx to the rigid salpingoscope (used in the present study) that allows detailed visualization of the endosalpinx with the possibility of magnification up to 80 times. The use of the rigid salpingoscope required modification of the technique and yielded clear and specific view of the endotibal mucosa. Again, this discreapancy can be explained by the small number of patients included int he present study (30 cases) compared with (200 cases) included in their study.

Our present study depicted that when tubal pathology was suspected by laparoscopy (in $23.73 \%$ ), salpingoscopic evaluation revealed that $5.1 \%$ of these 
tubes were free of intratubal pathology. These findings agree with that reported by some authors $(21,22,23$ and 24$)$.

The current investigation revealed that the number of pregnancies among cases reported salpingoscopically normal (as shown in table V) was 17 cases $(56.7 \%$ and the number of pregnancies among cases found to be abnormal salpingoscopically and treated it was $10(33.3 \%)$. These abnormalities had Grades II and III intraluminal adhesions. This pregnancy rate is considered within the average range reported in previous studies $(19,25$ and 26$)$.

Last but not the least, we conclude that both laparoscopy and salpingoscopy are complementary procedures and their combination should be a standardized part of the work up of investigation of the infertile patients, especially in cases of unexplained infertility.

\section{REFERENCES}

I. Watrelot A, Hamilton J and Grudzinskas JG: Advances in the assessment of the uterus and fallopian tube function. In: Best Practice \& Research Clinical Obstetrics \& Gynecology. 2003: 17(2): 187-209.

2. Wentz AC: Infertility. In: Jones HW, Wentz AC, Nurnell LS (eds.) Novak textbook of Gynecology, 11th edition, Williams and Wilkins, USA. 1988; p 531.

3. Wallach C: The infertile couple. In: Beek WW (ed.) Obstetrics and gynecology, 2nd edition, John Wiley an Sons, USA. 1989; p 140.

4. Henry-Suchet J, Loffredo V. Tesquier L and Pez J: Endoscopy of the Fallopian tube (tuboscopy): Its prognostic value for tuboplasty. Acta Europ Fert. 1985; 16: 139-145.

5. Gordon AG and Scudamore IW: Tubal endoscopy; In: Gordon AG, Hulka JF, Walker DM and Campana A (eds.): Practical training and Research in gynecologic endoscopy. London, Mosby-Wolfe, 2000.

6. Brosens IA, Boeckx W, Delattin PH, and Puttemans P. Vasquez G: Salpingoscopy: a new preoperative diagnostic tool in tubal infertility. Br J Obst Gyn. 1987, 94: 768-773.

7. Burn CL: Principles of Midwifery. Longman, Hurst, Rees and Orme, London 1809; 131-132.

8. Ledeer $\mathrm{KJ}$ : Transcervical tubal cannulation and Salpingoscopy in the treatment of tubal infertility. Curr Opin Obstet Gynecol. 1993; 5(2): 240-244.

9. Hulka J and Halme J: tubal disease. In: Infertility: A practical guide for the physician 3rd edition, edited by Hammond M.G. \& Talbert M.L. Boston
Blackwell scientific publications Oxford: London. Edinburgh, Melbourne, Paris, 1992; P: 122.

10. Sulak PJ, Letterie GS and Coddington CC: Histology of proximal tubal occlusion (PTO). Fertil Steril. 1987; 48: 437-440.

11. Kerin JF, Williams DB, San Roman GA, Pearistone AC, Grunfest WS and Surrey ES: Falloposcopic classification and treatment of Fallopian tube lumen disease. Fertil Sterl. 1992; 57: 731-741.

12. Adelusi B, al-Nuaim L, Makanjuola D, Khashaggi T, Chowdhurry N Kngave D: Accuracy of HSG and laparoscopic hydrotupation in diagnosis of tubal patency. Fertil Steril. 1995; 63: 1016.

13. Rice JP, London SN, Olive D:: Re-evaluation of hysterosalpingography in infertility investigation. Obst Gyn. 1986; 67: 718.

14. Cornier E: L'ampulloscopie per-coelioscopie. Journal de Gynecologie, Obstetrique et Biologie de in Reproduction (Paris). 1985; 14: 459-466.

15. Marana R., Muzii L, Rizzi M, Muscatello P, Dell'Acyuas and Mancuso S: Salpingoscopy in patients with contralateral ectopic rpregnancy. Fertil. Steril. 1991; 55: 838-840.

16. Shapiro BS, Diamond MP and De Chemey AH: Salpingoscopy: an adjunctive technique for evaluation of the fallopian tube. Fertile Steril. 1988; 49: 1076-1079.

17. Marana R and Quagliarello J: Microsurgery versus IVF- a review. Int J Fertil., 33: p 338, 1988.

18. Dubuisson JB, Chapron C, Morice P, Aubriot FX, Foulot $\mathrm{H}$ and de Joliniere TB: Laparoscopic salpingostomy: fertility results according to the tubal mucosal appearance. Hum Reprod. 1994; 9: 334-339.

19. Puttemans PJ, Brosen IA, Delattin PH, Vasquez G and Boeckx W: Salpingoscopy versus hysterosalpingography in hydrasalpinges. Human Reprod. 1987; 2: 535-540.

20. Boweman $M$ and Cooke I: Comparison of fallopian tube intraluminal pathology as assessed by salpingoscopy with pelvic adhesion, Fertil Steril. 12996; 61: 464-469.

21. Puttemans PJ, De Bruyne FD and Heylen SM: A decade of salpingoscopy. European J of Obt Gyn Reprod Biol. 1998; 81: 197-206.

22. Nezhat FR, Winer WK and Nezhat CR: Fibrioscopy and salpingoscopy in patients with minimal moderm pelvic endometriosis, Obst Gyn., 75: p 15, 1993.

23. Vasquez G, Boeckx $W$ and Brosens I: No correlation between peritubal and mucosal adhesions in hydrosalpinges. Fertil Steril; 1995(a); 64: 1032-1033.

24. Vasquez G, Boeckx W and Brosens I: Prospective study of tubal mucosal lesions and fertility in hydrosalpinges. Hum Reprod. 1995(b); 10: 1075-1078.

25. Heylen SM, Brosens IA and Puttemans PJ: Clinical value and cumulative pregnancy rates following rigid salpingoscopy during laparoscopy for infertiltiy. Hum Reprod. 1995; 10: 2913-2916.

26. Surrey E: Microendoscopy of the human fallopian tube. Journal of the American Association of Gynecologic Laparoscopists; 2000; 6: 383-387. 